Arq. Bras. Med. Vet. Zootec., v.67, n.5, p.1226-1230, 2015

\title{
Histopathological hoof laminar changes in horses with Pituitary Pars Intermedia Adenoma: cases report
}

\author{
[Alterações histopatológicas do tecido laminar do casco em cavalos com adenoma da \\ Pars Intermedia da Hipófise: relato de casos] \\ L.M. Laskoski $^{1}$, R. Locatelli Dittrich $^{1}$, C.A.A Valadão ${ }^{2}$, M.L. Castro ${ }^{1}$, F.F. Araujo ${ }^{1}$, \\ J.R. Silva ${ }^{1}$, F.Z. Basso ${ }^{1}$, P.T. Dornbusch ${ }^{1}$, I. Deconto ${ }^{1}$, R.S. Sousa ${ }^{1}$ \\ ${ }^{1}$ Universidade Federal do Paraná, UFPR - campus Curitiba, PR \\ ${ }^{2}$ Universidade Paulista “Júlio de Mesquita Filho”- UNESP - campus Jaboticabal, SP
}

\begin{abstract}
Laminitis in horses is often associated with endocrine disorders, especially the pituitary pars intermedia dysfunction (PPID) in older animals. Morphologic exams of the laminar tissue of the hoof were performed in two horses with suspected PPID, with no clinical signs of laminitis. Changes compatible with laminitis of endocrine origin were observed, such as rounding of the nuclei of the basal cells, thinning and stretching of the secondary epidermal laminae and tissue proliferation. PPID horses with no clinical signs of laminitis may be affected by lesions of the laminar tissue of the hoof that compromise the integrity of the dermal-epidermal junction and may develop clinical symptoms of the disease. It has been suggested that the development stage of endocrine laminitis is longer, but further studies should be conducted to confirm it.
\end{abstract}

Keywords: laminitis, metabolic syndrome, Cushing's syndrome, endocrine disorders, pituitary adenoma

\section{RESUMO}

A laminite em cavalos está frequentemente associada a distúrbios endócrinos, como a disfunção da pars intermedia da pituitária (PPID) em animais mais velhos. Exames morfológicos do tecido laminar do casco foram realizados em dois cavalos com suspeita de PPID após o óbito, os quais não apresentaram sinais clínicos de laminite. Alterações compatíveis com a laminite de origem endócrina foram observadas, como arredondamento da núcleo das células basais, alongamento e afilamento das lâminas epidérmicas secundárias e proliferação tecidual. Cavalos com PPID sem sinais clínicos de laminite podem estar acometidos por lesões do tecido laminar do casco que comprometam a integridade das interdigitações dérmico-epidérmicas e podem desenvolver a sintomatologia clínica da doença. Sugere-se que o período de desenvolvimento da laminite endócrina seja mais longo, porém estudos adicionais devem ser realizados para confirmar essa hipótese.

Palavras-chaves: laminite, síndrome metabólica, síndrome de cushing, alterações endócrinas, adenoma de pituitária

\section{INTRODUCTION}

Laminitis is a disease that affects the horse's feet and is often fatal as a result of the severity of the injury and painful discomfort. Hormonal disorders are associated with its development (Johnson et al., 2004), as in the pituitary pars intermedia dysfunction (Donaldson et al., 2004), probably due to increased circulating insulin, confirmed by induction models of laminitis using the administration of hormones (de Laat et al., 2013). The pituitary pars intermedia dysfunction (PPID) that affects older horses (over 15 years old), also known as Cushing's syndrome, occurs by oxidative damage in the dopaminergic neurons of the hypothalamus, which function is to inhibit the secretion of pituitary hormones.

Recebido em 2 de junho de 2014

Aceito em 23 de dezembro de 2014

E-mail: luci.laskoski@gmail.com 
The inhibitory failure leads to excessive hormone production and causes the hypertrophy of pituitary pars intermedia (McFarlane et al., 2005), and hirsutism is the main clinical sign. Other signs include recurrent respiratory infections due to increased endogenous cortisol (Johnson et al., 2004), fat deposition in the supra-orbital fossae, muscle loss, polyuria and polydipsia (McGowan, 2003; McFarlane, 2011). However, most of the horses suffering from PPID started treatment based on clinical signs of laminitis (Donaldson et al., 2004). Schott et al. (2001) observed PPID in 77 horses, using characteristic clinical signs and the dexamethasone suppression test, and 53 of them demonstrated laminitis.

The aim of this report is to demonstrate morphological changes in the hoof laminar tissue of two horses sent for necropsy with suspected pituitary pars intermedia dysfunction, which had never shown any clinical signs of laminitis.

\section{CASUISTIC}

Necropsies were performed on two male horses aged over 18, with a history of recurrent respiratory infections, polyuria and polydipsia, intense sweating and hirsutism. Loss of muscle mass and fat deposition in the supra-orbital fossae was observed during inspection. There were no clinical signs of laminitis in any of the horses. The examination proceeded routinely, with the collection of fragments of all the organs of the thoracic and abdominal cavities. After the skull was opened an increase in the volume of the pituitary gland in both animals was observed, then the collection of the glands was carried out.

Limbs were disarticulated at the metacarpophalangeal joints for hoof laminar tissue collection and subsequent sagittal section of the hoof was performed to remove the tissue using a scalpel and forceps (Pollitt, 1996).

After 48 hours fixation in formaldehyde, all tissues were routinely processed for histopathologic evaluation. Histological sections of $5 \mathrm{~mm}$ thickness were stained with hemotoxylin and eosin (HE) for further observation using an optical microscope. The hoof laminar tissue was stained with Periodic Acid Schiff (PAS) to evaluate the integrity of the basal membrane. Display microscopy was used to identify the pituitary tumor, and for the evaluation of the morphological changes of the hoof laminar tissue in both horses. The changes were assessed based on rating scores 0-3 defined by Pollitt (1996), and the results reported by de Laat et al. (2013).

Histopathologic evaluation of the pituitary tumors in both horses revealed an adenoma of the pars intermedia characterized by the presence of a well demarcated and unencapsulated neoplastic proliferation which was organized in lobes separated by a discrete fibrovascular stroma. Neoplastic cells within these lobes were arranged in strands and cell nests, which contained slightly polygonal spindle cells with mild anisocytosis and moderate anisokaryosis. The cytoplasm of neoplastic cells was eosinophilic and finely granular, and the nucleus was oval and hyperchromatic, with 1-3 nucleoli.

Considering the morphological evaluation of the hoof laminar tissue by HE and PAS staining, it was observed that the two horses had abnormalities on the four limbs ranging from 12. The main changes were rounding of the basal cell nuclei, thinning and stretching of secondary epidermal laminae, undulations of the primary epidermal laminae, basal membrane with a serrated and blurred appearance and absence in some segments of the laminar tissue (Fig. 1).

The diagnosis of PPID was confirmed by the presence of clinical signs consistent with the disease, such as hirsutism, fat deposition in the supra-orbital fossae, muscle mass loss, injury in the laminar tissue of the hoof and characteristic alterations of adenoma of the pituitary pars intermedia in both horses. 


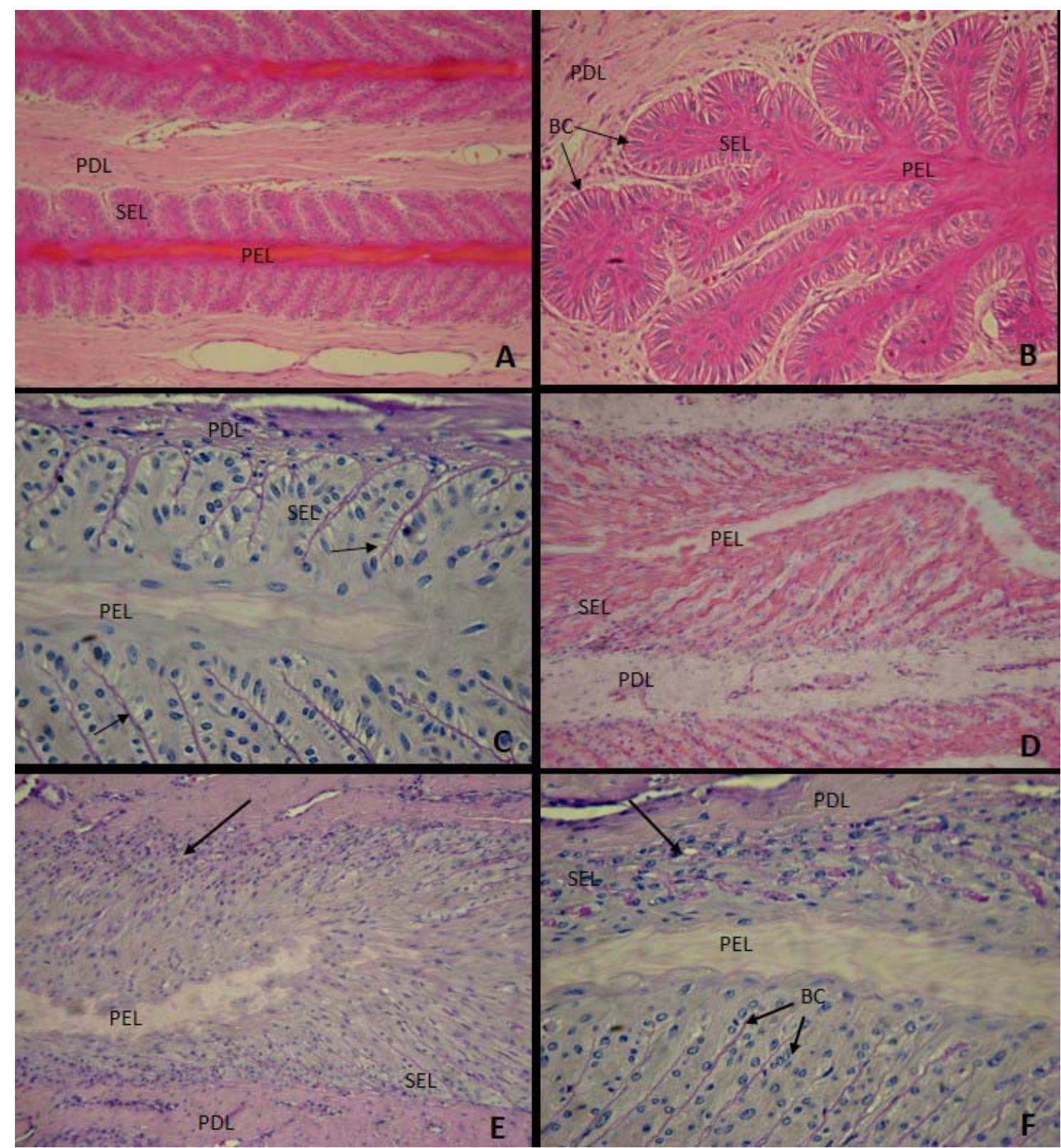

Figure 1. Photomicrograph of the hoof laminar tissue of the horses with PPID. Morphological changes ranging from 1-2 degrees. A. Interdigitations between dermal and epidermal laminae (Degree 0, 20x, HE). B. Rounded SEL, with oval BC nuclei (arrows) (Degree 0, 40x, HE). C. BM evident between the interdigitations (arrows) (Degree 0, 40x, PAS). D. Elongated and tapered SEL. Undulations of PEL (Degree 2, 20x, HE). E. Undefined contour of BM (arrows) in disorganized SEL (Degree 2, 20x PAS). F. Undefined and absence of the BM in SEL. BC rounded nuclei (arrows) in SEL (Degree 2, 40x, PAS). SEL: Secundary epidermal laminae; BC: basal cell; BM: basal membrane; PEL: primary epidermal laminae.

\section{DISCUSSION}

Morphological changes of hoof laminar tissue have been studied for two decades, and were first described by Pollitt (1996), whose main aim was to demonstrate the loss of integrity of the joints formed by the dermal and epidermal laminae. Morphological changes found in laminar tissue of animals in this report were consistent with the changes described by Pollitt (1996), by 
observing the round shape of the nucleus of basal cells (BC), lengthening of the secondary epidermal laminae (SEL) and modified segments of the basal membrane (BM) contour, that were serrated, blurred and sometimes even absent. Pollitt and Visser (2011) demonstrated that the changes in the BM are the earliest events that occur during the developmental phase of laminitis induced by the administration of oligofructose, a model for the induction of inflammatory laminitis. In the current report, the main changes were in the $\mathrm{BM}$ regarding its outline, mostly undefined and absent in some segments, a result that was similar to that obtained by de Laat et al. (2013), in serial histologies of the laminar tissue of horses with insulin induced laminitis. The result obtained by the authors suggests that the separation of the BM occurs secondary to initial injury, since it was possible to observe morphological changes related to the nuclei of the $\mathrm{BC}$ and organization of primary epidermal laminae (PEL) and secondary epidermal laminae (SEL) prior to the change of BM. de Laat et al. (2010) observed the development of laminitis after insulin administration with clinical manifestation of the disease, such as hoof sensitivity and lameness, and with the histopathological assessment of the laminar tissue showing cell proliferation, thinning of SEL, rounded BC oriented perpendicular to the BM. However, these findings differ from those described by Pollitt (1996) in its classification as grade 3 associated with obvious symptoms of laminitis, such as the absence of BM and severe destruction of the lamellar architecture of the hoof. Therefore, the results in this report were similar to those described by de Laat et al. (2010) and de Laat et al. (2013).

Nourian et al. (2009) observed changes in the laminar tissue of ponies suffering from induced hyperinsulinemia related to cell proliferation due to intense mitosis and small areas with separation of the basal membrane, changes that are likely to weaken the laminar apparatus. These findings relating to a remodeling of the laminar tissue are found in chronic laminitis (Johnson et al., 2004) and perhaps this difference in morphology of endocrinopathic laminitis is responsible for milder disease symptoms, compared with laminitis of inflammatory origin. Since laminitis associated with hormonal changes usually occurs in the chronic phase (Donaldson et al., 2004), it is assumed that its development phase in naturally occurring cases leads to a subtle and progressive remodeling of the laminar tissue of the hoof, which can manifest clinically in the chronic phase of laminitis (Johnson et al., 2004). This assumption is supported by the studies of Polzer and Slater (1996), who observed a high incidence of chronic laminitis in older horses, which can be associated with the development of PPID (Karikoski et al., 2011). In the studies of associations between laminitis and age no significant associations were found between acute and chronic phase and no increase in hoof disease was observed in older horses (Wylie et al., 2011). The animals in this report had not shown any clinical signs of laminitis; however, morphological findings showed breakdown in the integrity of the hoof laminar tissue, suggesting that the disease could manifest itself sooner or later.

Laminitis that occurs secondary to the inflammatory processes has its severity related to the underlying disease and may lead to loss of hoof and death of the animal. Serious changes in the laminar tissue of the hoof occur rapidly in the induced laminitis (Pollitt et al., 1996; Visser and Pollitt, 1996) as secondary to colic syndrome. Laminitis of endocrinopathic origin rarely causes severe pain, even if the rotation of the distal phalanx has already occurred, resulting in a milder form of the disease. Many animals can even show structural changes in the hoof not associated with claudication (Johnson et al., 2004). There are no studies indicating the moment in which the hoof disease arises in horses suffering from PPID, and based on the results of this report, it is believed that all horses suffering from this disease are susceptible to develop laminar lesions, although not sufficient to cause painful symptomatology. In addition, it is suggested that the development stage of changes in the laminar tissue in naturally occurring endocrinopathic laminitis is longer than that observed in laminitis of inflammatory origin.

In some countries hormonal changes play an important role in the development of laminitis. In Britain, hormonal changes are the most common cause of laminitis in horses, with the PPID value of 21.3\% (Wylie et al., 2011). Donaldson et al. (2004) showed that 7\% of horses suffering from laminitis treated at a clinic in the United States 
(USA) were diagnosed with PPID. Karikoski et al. (2011) observed that $89 \%$ of 36 horses presented for laminitis at an equine hospital showed endocrine disorders, and one third of the animals were diagnosed with pituitary pars intermedia dysfunction. The early association of laminitis to a primary cause enables the treatment of the underlying disease, thereby obtaining better results for laminitis.

\section{CONCLUSION}

Horses suffering from PPID have shown changes in hoof laminar tissue that do not necessarily result in painful manifestation, but can cause changes to the hoof structure. It is suggested that the prodromal stage of naturally-occurring endocrinopathic laminitis is slower and milder than the inflammatory laminitis.

\section{REFERENCES}

DE LAAT, M.A.; MCGOWAN, C.M.; SILLENCE, M.N.; POLLITT, C.C. Equine laminitis: Induced by $48 \mathrm{~h}$ hyperinsulinaemia in Standardbred horses. Equine Vet. J., v.42, p.129135, 2010.

DE LAAT, M.A.; PATTERSON-KANE, J.C.; POLLITT, C.C. et al. Histological and morphometric lesions in the pre-clinical, developmental phase of insulin-induced laminitis in Standardbred horses. Vet. J., v.195, p.305-312, 2013.

DONALDSON, M.T.; JORGENSEN, A.J.; BEECH, J. Evaluation of suspected pituitary pars intermedia dysfunction in horses with laminitis. J. Am. Vet. Med. Assoc., v.224, p.1123-1127, 2004.

JOHNSON, P.J.; MESSER, N.T.; SLIGHT, S.H. et al. Endocrinopathic laminitis in the horse. Clin Tech. Equine Pract., v.3, p.45-56, 2004.

KARIKOSKI, N.P.; HORN, I.; MCGOWAN, T.W.; MCGOWAN C.M. The prevalence of endocrinopathic laminitis among horses presented for laminitis at a first-opinion/referral equine hospital. Domest. Anim. Endocrinol., v.41, p.111-117, 2011.
MCGOWAN, C.M.; NEIGER, R. Efficacy of trilostane for the treatment of equine Cushing's syndrome. Equine Vet. J., v.35, p.414-418, 2003.

MCFARLANE, D.; DYBDAL, N.; DONALDSON, M.T. et al. Nitration and Increased a-Synuclein Expression Associated With Dopaminergic Neurodegeneration In Equine Pituitary Pars Intermedia Dysfunction. J. Neuroendocrinol., v.17, p.73-80, 2005.

MCFARLANE, D. Equine pituitary pars intermedia dysfunction. Vet. Clin. North Am. Equine Pract., v.27, p.27:93-113, 2011.

NOURIAN, A.R.; ASPLIN, K.E.; MCGOWAN, C.M. et al. Equine laminitis: ultrastructural lesions detected in ponies following hyperinsulinaemia. Equine Vet. J., v.41, p.671677, 2009.

POLLITT, C.C. Basement membrane pathology: a feature of acute equine laminitis. Equine Vet. J., v.28, p.38-46, 1996.

POLZER, J.; SLATER, M.R. Age, breed, sex and seasonality as risk factors for equine laminitis. Prev. Vet. Med., v.29, p.179-184, 1996.

SCHOTT, H.C.; COURSEN, C.L.; EBERHART, S.W. et al. The Michigan Cushing's Project. AAEP Proceedings, v.47, p.22-24, 2001. Available in: <http://www.ivis.org/proceedings/ aaep/2001/91010100022.pdf> accessed in: 4 fev. 2014.

VISSER, M.B.; POLLITT, C.C. The timeline of lamellar basement membrane changes during equine laminitis development. Equine Vet. J., v.43, p.471-477, 2011.

WYLIE, C.E.; COLLINS, S.N.; VERHEYEN, K.L.P.; NEWTON, J.R. Frequency and speculated causes of equine laminitis in Great Britain. In: Proceedings of the 50th British Equine Veterinary Association Congress, p.87, 2011. Available in: <http://www.ivis.org/proceedings/beva/2011/clin _research/2.pdf> accessed in: 26 nov. 2014. 